\title{
MARITIME SOUTHEAST ASIA IN GLOBAL TRADE IN PRE-MODERN TIMES: A HISTORICAL GEOGRAPHY PERSPECTIVE
}

\author{
${ }^{1}$ Loh Wei Leng* \& ${ }^{2}$ Chi Seck Choo \\ *first author \\ ${ }^{1}$ Institute of Ocean and Earth Sciences (IOES), \\ University of Malaya, Kuala Lumpur \\ Malaysia \\ ${ }^{2}$ Independent Researcher \\ (lohwl2002@yahoo.com) \\ DOI: https://doi.org/10.22452/samudera.vol1no1.1
}

\begin{abstract}
From the earliest centuries, there is evidence of the participation of various communities in the Southeast Asian region in global trade between Europe, India and China. One of its components was between China and Maritime Southeast Asia, which focused on trade in the South China Sea and the Straits of Melaka. Maritime Southeast Asia developed, first as suppliers of regional goods and services, next as the transit foci of routes extending to the Indian Ocean and the Mediterranean. The region also attracted new migrant communities as sojourners, settlers and colonists vying for the control of the flow of goods and services, giving rise to an intricate pattern of complex local, regional and global trade networks. As new types of products, routes and markets emerged in dynamic and ever-changing patterns, some of the communities were wiped away, while others re-grouped to form new social and economic alliances. New political, social and economic liaisons and mobility resulted in the formation of acculturated minority communities. This paper is part of a broader study of the contribution of one such minority sub-community, i.e., the Peranakan Chinese in maritime Southeast Asia in the period when the China-Southeast Asia component of the East-West trade had its most significant impact on the social and economic development of the region, i.e., the eighteenth to the nineteenth centuries.
\end{abstract}

Keywords: trading communities, regional commerce, maritime Southeast Asia, Peranakan Chinese

World historians have shown global trade to exist from pre-historic times, involving the world known to those inhabiting it, in particular, the "Old World" of Afro-Eurasia, leaving the "New World" of the Americas to be included in global trade from around the 15th century. As Abu-Lughod (1989) and Chaudhuri (1985) have aptly illustrated, east-west trade has not been conducted by one set of merchants travelling from one endpoint to the other. Merchants have been primarily confined to trade within their regions, meeting at intersecting sites for exchanges, the ports which rose to become 
trading centres. They served as emporiums and entrepots where goods were collected from hinterlands before being transshipped and transported to minor ports or for export further afield to other regions.

This article examines maritime Southeast Asia as one region and a key segment in the global trade of Afro-Eurasia prior to European entry into Asia, along the lines of world system models of Andre Gunder Frank and Philippe Beaujard, who argue that globalization processes were in operation long before the modern period, rejecting Immanuel Wallerstein's thesis which posits the origins of the world economy from the sixteenth century. The article makes the argument that trade diasporas can serve as a tool to illuminate strong links with the larger trading world.

This essay has two components. The first is the highlights of the globalised nature of the Silk Road trade, a lens to view the growth and development of a transcontinental system of commerce that has evolved since antiquity. The second part focuses on maritime Southeast Asia and the role that this region played in the Silk Road trade. Maritime Southeast Asia participated as suppliers of regional goods and as the transit focus of routes extending from China to India and Europe via the Indian Ocean and the South China sea routes. Several trade diasporas have emerged in Southeast Asia as a consequence of this east-west trade. This article is part of an ongoing effort to ascertain the role of a specific trade diaspora, the Peranakan Chinese in the Straits of Melaka.

\section{World System Models Revisited}

Wallerstein originally conceived the idea of a single global (economic) system in 1974. He postulated that in the sixteenth century, Eurasia, the Mediterranean, the Indian Ocean and the South China Sea became a unified space through exchange networks, geographically stretching out from China to Europe and Africa.

Abu-Lughod (1989) presented a groundbreaking reinterpretation of Wallerstein's global economic evolution, arguing that the modern world economy had its roots back in the thirteenth century. Using the city as the working unit of analysis, she provided a new paradigm for understanding the evolution of world-systems by tracing the rise of a system that, at its peak in the opening decades of the 14th century, involved a vast region stretching between northwest Europe and China.

Frank holds a different view that the World System has been developing for over five thousand years. He defined his world system as a systematic network of trade which had origins in Mesopotamia, Egypt and the Indus into the Asia-Afro European oecumene and incorporated the western hemisphere after the sixteenth century AD (Frank \& Gills 1994).

Beaujard (2005) proposes yet another "World System" model. He postulates that from a very early date, the Indian Ocean was traversed by sailors, traders, religious men, and migrants moving in search of goods, new lands, or the great unknown. "These exchanges transformed the Indian Ocean into a unified space embedded in a Eurasian and African world-system" (p. 411).

Beaujard (2005) argued that by the end of the second century AD, the vast network of overland and maritime trade routes traversed across eight major economic zones including (1) The Han Empire and the "Western Regions", (2) the Kushan 
Empire, (3) the Parthian Empire, (4) the Roman Empire, (5) the Arabian Coast, (6) the coastal belt of East Africa, (7) the Indian sub-continent and Sri Lanka, and (8) Southeast Asia (see Figure 1).

The fact that the different regions of the ancient world united by trade experienced a demonstrable synchronization in their development suggests the systemic nature of their relations....It is not only the interconnections or the size of the networks but the regularity, intensity, and speed of the exchanges that resulted in the different regions being progressively integrated and shaped into a world-system (Beaujard 2005:412)

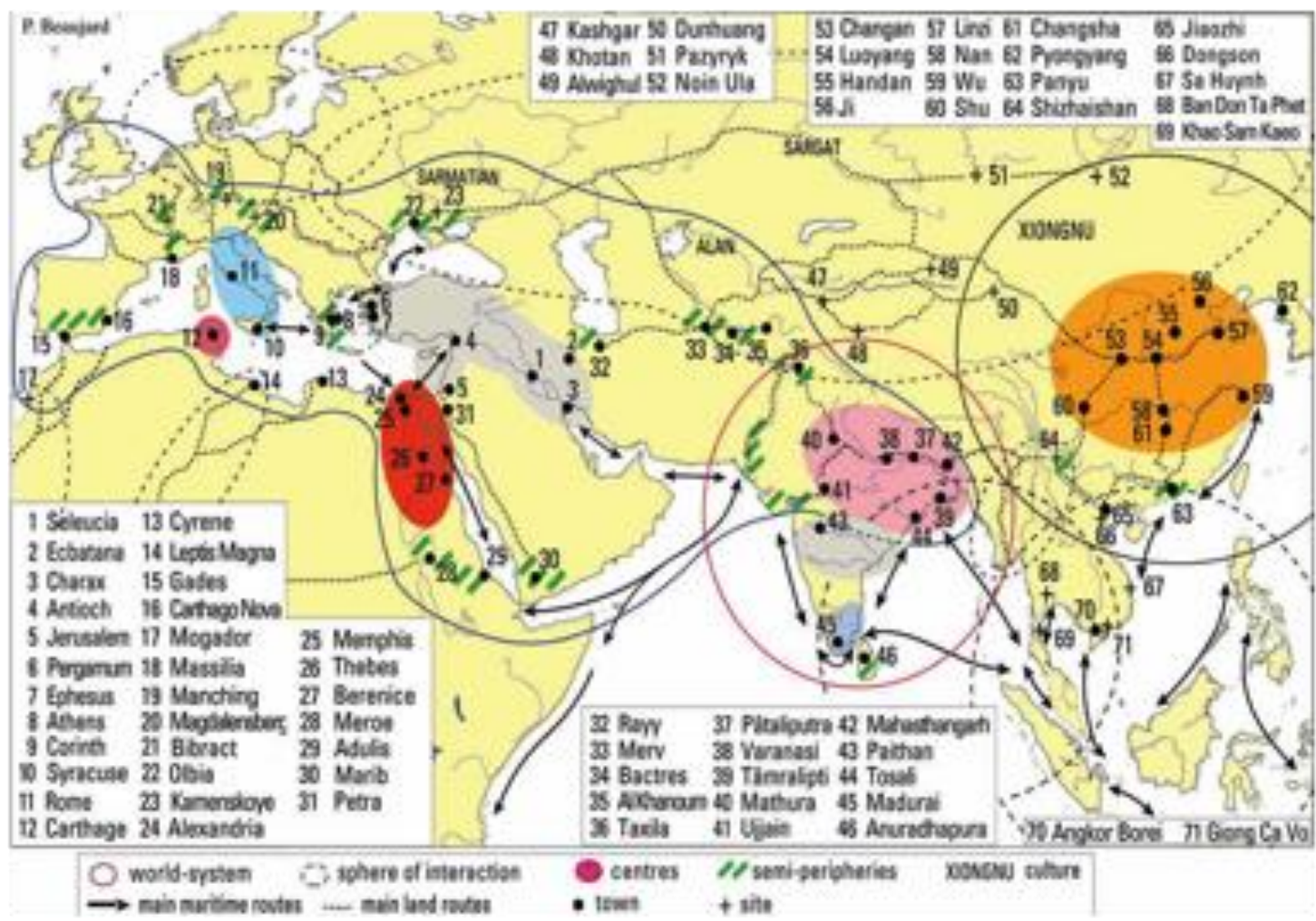

Figure 1: Beaujard's Generalized Structure of the Afro-World System from 350 BC to the end of the first millennium

Source: Beaujard, P. (2010)

\section{The "Great Silk Road" Trade Network (c. 220 AD)}

The works of Frank, Abu-Lughod and Beaujard incorporated ancient trade on the Great Silk Route as an integral part in the evolution of a global trade system (Frank, 1992; Abu-Lughod, 1989; Beaujard, 2010). The Silk Road has long been enshrined as a symbol of cross-cultural exchange of commodities, technology and religions. Though it was initially the demand for silk which first fuelled and kept global trade going for 
centuries on its routes, the Silk Road was also an important avenue for the flow of many products, plants, animals and even diseases (Lawton, 2004).

The Silk Road comprised two main inter-connecting networks, overland and maritime routes (see Figure 2). The overland portion of the Silk Road was not a single route but comprised of several interlinking routes. From its eastern end, the route started from Chang'an (Xian) westwards via Central Asia with routes converging in Kashgar (Shule) and from there, branched out to the port towns in the Mediterranean Sea such as Alexandria, Antioch and Constantinople (Istanbul) reaching the final destination in Rome. Between China and Rome, overland trade was organised around intermediaries and middlemen merchants, with goods changing hands several times during a journey which could last for several months or years because of the dependence on horses, camels and mules for transport.

The marine Silk Road developed concurrently with the overland routes. The Houhanshu (History of the Later Han Dynasty, 25-220 AD) records that the first envoy from Rome arrived in China by the maritime route in $166 \mathrm{AD}$, initiating a series of Roman contacts with China (Shen Fu Wei 1996: 43). By 200 AD, major ports connected the overland to the maritime routes of the Silk Road. In later years, during the Song (960-1279) and the Yuan Dynasty (1271-1368), this route became popularly known as the "Marine Ceramic Road" as porcelain gradually became the main export in place of silk. At this time it also carried a lot of spices and the "Spice Routes" became part of the Silk Road trade system.

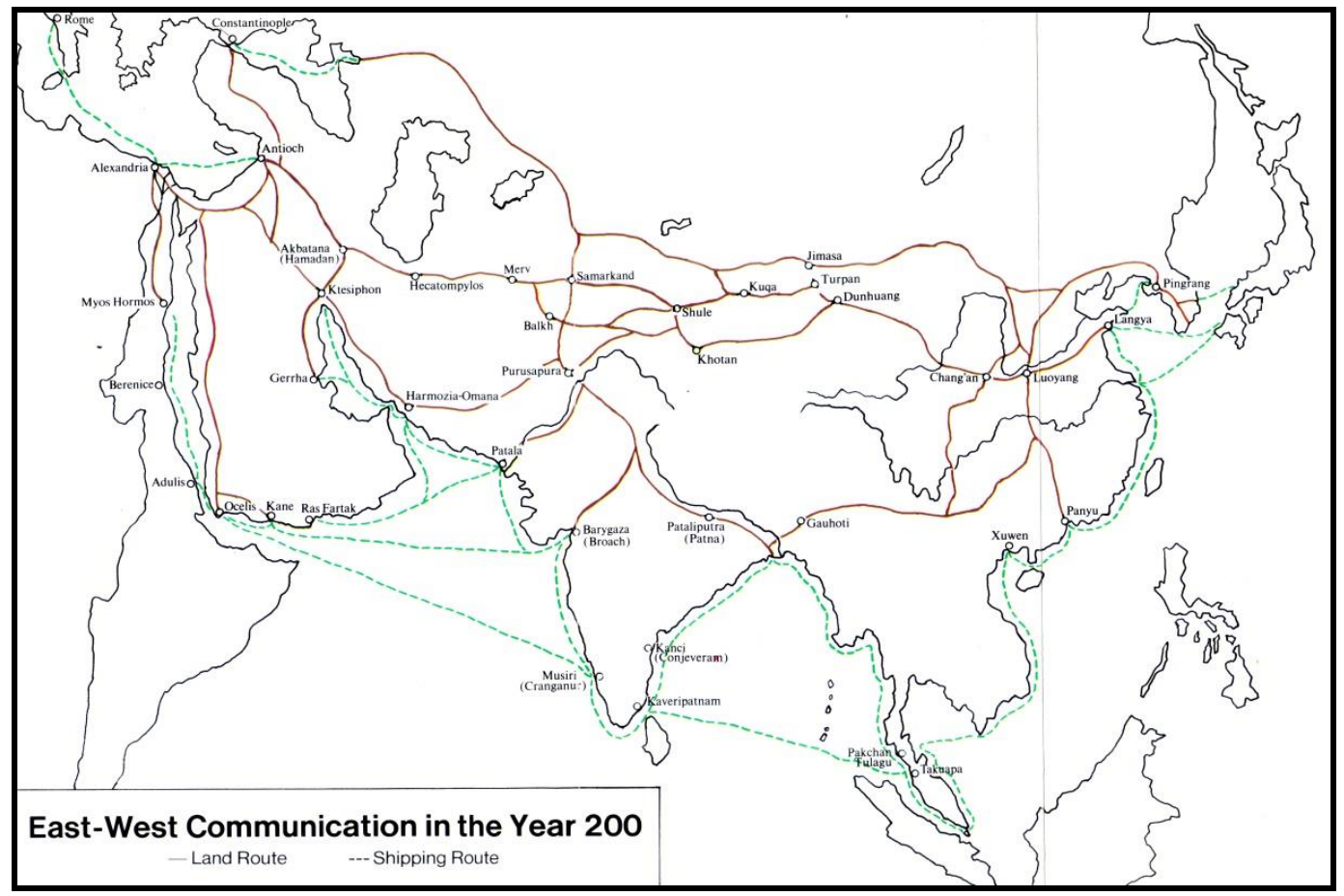

Figure 2: Main Routes of The Great Silk Road c.200 AD

Source: Shen Fu Wei (1996) 
There were two major branches in the spice routes (Figure 3). The cinnamon route started in northern Indochina and southern China and proceeded southward down the Philippines corridor to Sumatra and/or Java to pick up different varieties of cinnamon and cassia along with aloeswood and benzoin. Indonesian-Malay traders were the first to develop a long-distance trade in a southern spice route. They crossed the Sunda Straits towards the Indian Ocean to Africa possibly via island clusters such as the Maldives and Seychelles. The spices might have landed initially at Madagascar, then transported to the East African trading ports in and around the city known in Greco-Roman literature as Rhapta. The second was a "Clove Route" from Maluku and the southern Philippines, South China, Indochina and along the coast to the Straits of Melaka, thereafter to Indian spice markets and pointed further west. This ancient maritime route is chronicled in Arabic historical and geographic writings (Miller 1969: 153-172).

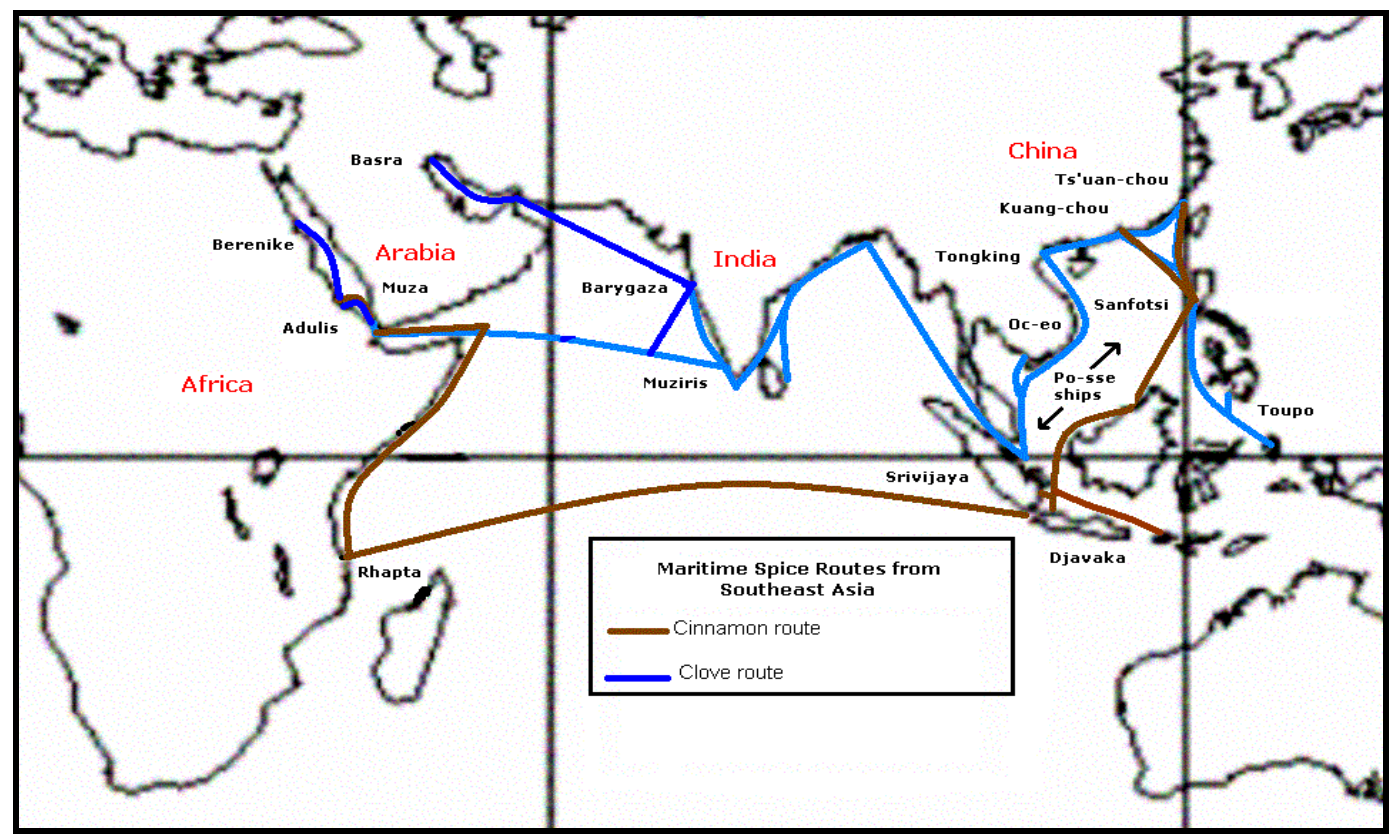

Figure 3: Maritime Spice Routes From Maritime Southeast Asia c. 200 AD Source: http://www.ipekyollari.net/SilkSpiceIncenseRoutes.htm

Integration of Maritime Southeast Asia into the Global Trade System c. 200 AD

Maritime Southeast Asia had many strengths which enabled it to be integrated with the growing global trade network by 200 AD. Factors such as being the main spice region (especially the highly valued clove and nutmegs, cinnamon and camphor) was one. Maritime Southeast Asia was also a major supply region for a great variety of forest products in great demand in the vast markets of China, India and Greek/Roman Europe, including gold, tin as well as pepper, sandalwood and slaves. As far back as 200 BC, 
Sumatra and Peninsular Malaysia enjoyed a global reputation as sources of gold with the Romans referring to them as the "Golden Khersonese" (see Figure 4).

Its strategic geographical position at the crossroads of the maritime routes between China and the West was another factor which contributed to its easy integration into the global trade system. Since the direct maritime route from the Middle East to India and then to China was a long one, India and Southeast Asia became logical transhipment points with traders taking advantage of these Southeast Asian ports and those in Southern India and Sri Lanka (Lockard 2010).

There were two major trade routes in Maritime Southeast Asia which affected the rise and development of transhipment ports. An earlier route from Indian ports to Southeast Asia at first used the Isthmus of Kra. From this point, goods were carried overland to the other side of the Isthmus. Here goods could be reshipped to mainland Southeast Asia, to the Indonesian Archipelago or north to Guangzhou. In the earlier period, this trans-peninsular route was more in use than the second route, which was via the Straits of Melaka. The Straits of Melaka, sheltered from the strong winds of the monsoons, soon became the more popular route, particularly after the 4th century AD. Evidence of the Chinese by-passing Funan and use of the Melaka Straits came from the account of Buddhist pilgrim Fa-hsein in 413 AD (Legge 1886).

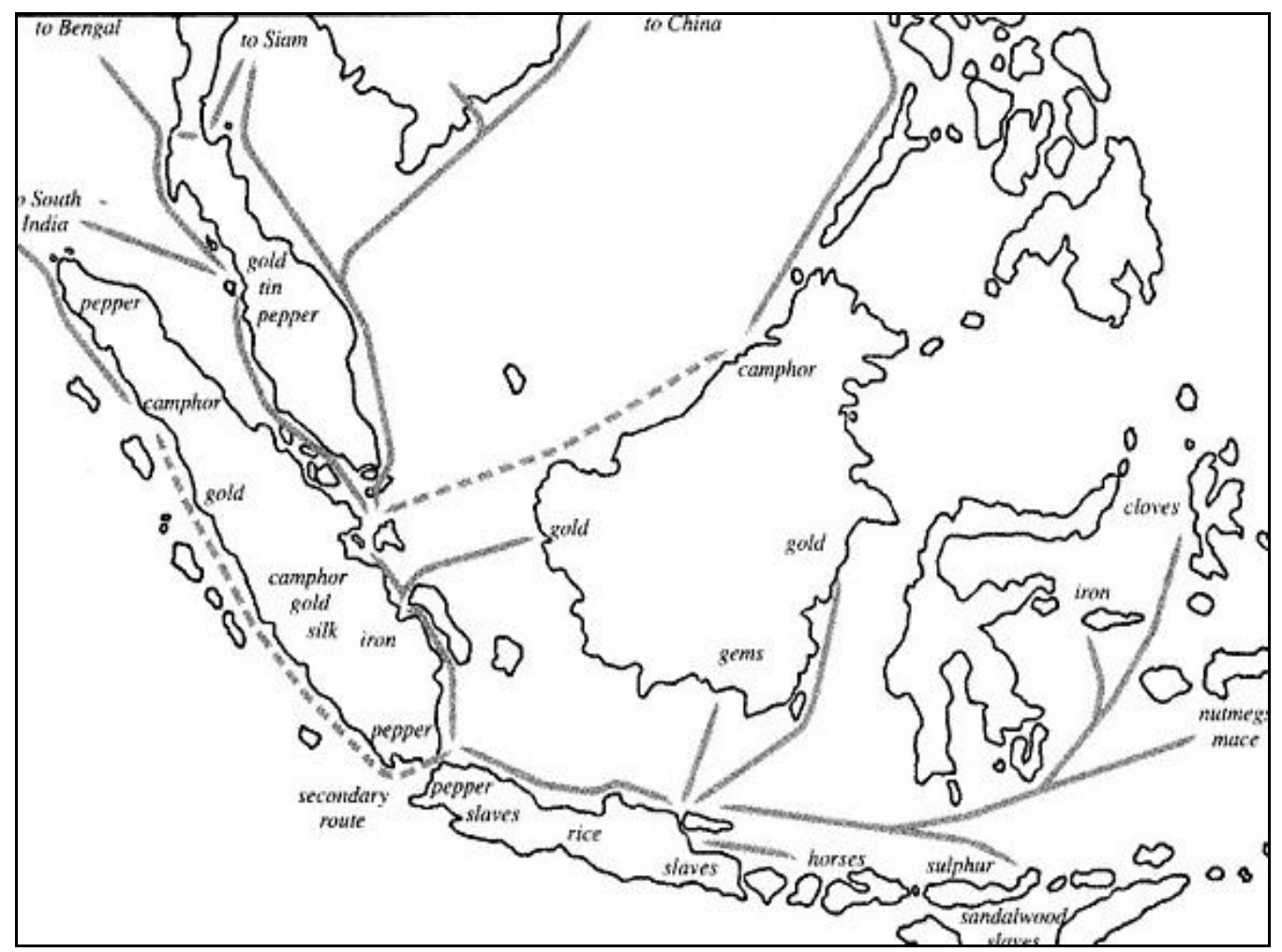

Figure 4: Natural Resources from Maritime Southeast in Global Trade c. 200 AD Source: Munoz, P.M (2006: 120) 
To achieve efficiency and effectiveness in the maritime routes, precise timing to catch the monsoon winds was vital for each ship's journey. Generally, the journey between the Persian Gulf to India or to maritime Southeast Asia would involve a few segments: (A) the Persian Gulf to the west coast of India, (B) longer hauls beyond the west coast of India to the east coast/the Bay of Bengal, and (C) If their destination was the Malay Peninsula, the vessels made for the Tenassarim coast.

For trip pattern (C) Arab vessels from the Gulf would aim to reach the Tenessarim coast by September to take advantage of the Southwest Monsoon. From October till December, these Gulf vessels await the arrival of the Chinese vessels which also follow the rhythm of the monsoon winds patterns. The Arab vessels were the first to leave the transhipment port by December, catching the Northeast Monsoon on their return journey to the Gulf. The Indonesian vessels bound for the south and southeastern parts of the archipelago were also able to sail back to their destinations from December onwards with the Northwest Monsoon. The Chinese vessels, however, had to wait until May in these transhipment ports to await their journey back to Guangzhou with the Southwest Monsoon (Munoz 2006: 70-71).

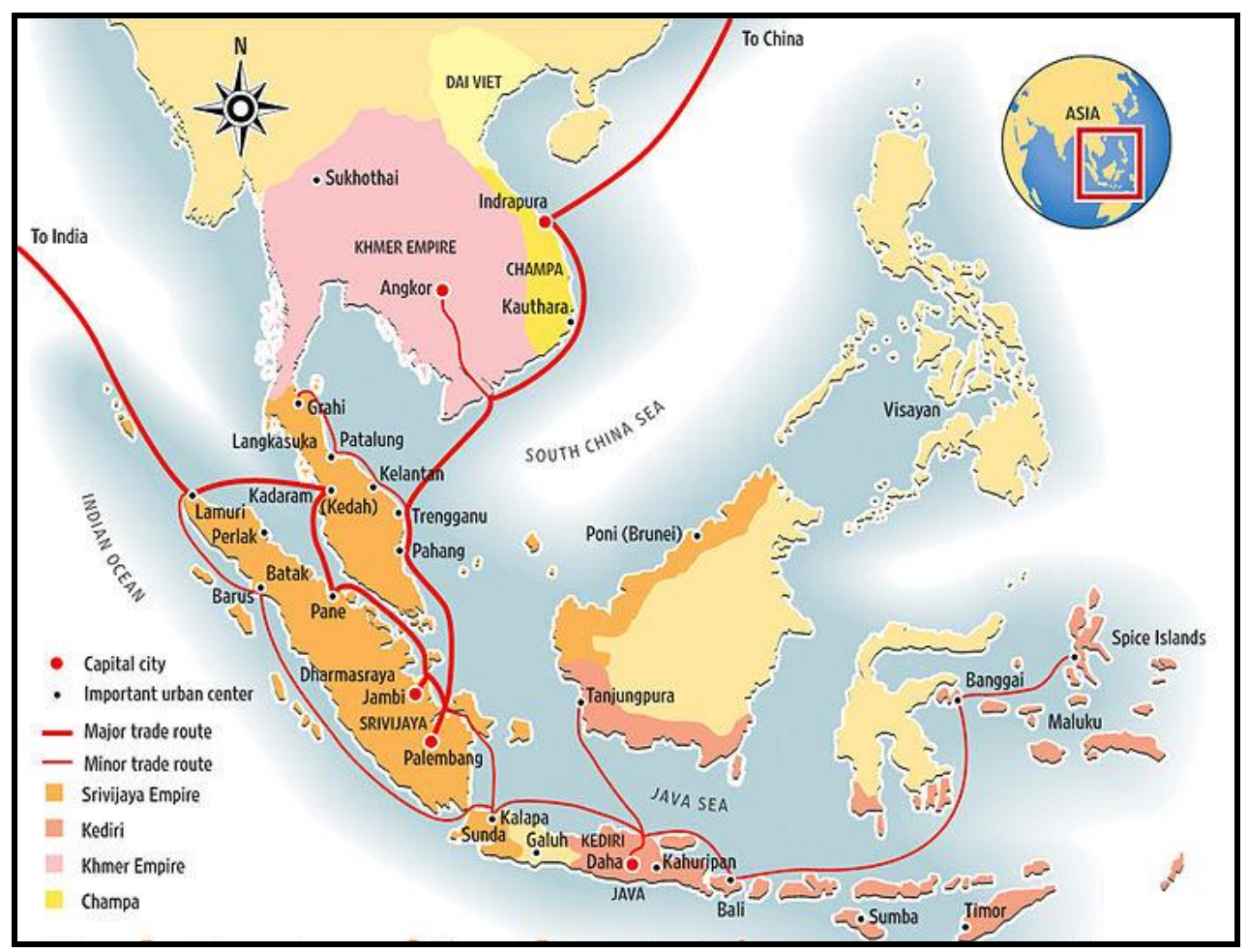

Figure 5: Main Trade Routes and Trade Centres in Maritime Southeast Asia 12th and 13th Centuries

Source: Achmad Jamil, Yulia Darmawaty, S.Pd, Sri Wachyuni, S.Pd and Mastara (2004: 32) 
Most Chinese vessels would travel between November to February from China, taking advantage of the Northeast Monsoon. The operation of transhipment would take place with eastbound cargoes sold and transshipped on to Chinese or Indonesian vessels and westbound cargo from the Indonesian and Chinese vessels transferred to the Arab vessels. In the second half of the eleventh century, the Song Dynasty restricted Chinese vessels from remaining abroad for more than nine months or one cycle of the monsoon winds. This meant that the Chinese vessels no longer went to the Bay of Bengal and the Indian Ocean. This also caused Chinese maritime traders to concentrate on Southeast Asia as one of the key markets that they could access directly. Knowledge about Southeast Asian ports increased tremendously from the late eleventh century onwards, and Chinese influence in the development of trade became more significant (Heng 2009: 51-53).

Yet another pattern emerged when shorter hops and more frequent trans-shipment gradually replaced the long voyages using Maritime Southeast Asia as transhipment points. This enhanced the value of regional ports, and a half dozen distinct port harbours cum trading centres rose in Southeast Asia, as shown in Figure 5. Some of the ports developed to become the global trade capitals of maritime polities such as Srivijaya, Majapahit and Melaka and the logical targets of trade diasporas.

This openness to outside influences of Southeast Asia was described as its preeminent characteristic. Anthony Reid noted that these trading polities of Southeast Asia were preoccupied with their relations with rival powers, for the control of other rivers and ports, in view of their commercial potential. "The activities of the whole population in the hinterland including hunters and gatherers of forest products, food growers, nomadic boat peoples, soldiers, labourers and slaves, even pirates were an integral part of this system" (Reid 2000; 5).

\section{Developments in Global Trade (c. 600 to 1500)}

Changes, economic and technological, fuelled developments in both the overland and maritime components of global trade after the seventh century. Several trends were discernible. As the trade expanded, other classes of goods were included. The overland Great Silk Route saw increased diversification with the flow of religions along the Silk Road which increased the demand for ornaments, special types of textiles, artefacts and other essentials required for religious purposes, classified as "luxury goods".

For the maritime routes, developments in shipbuilding promoted the use of large ships to attain economies of scale, comprising of at least 20-200 tons in a single boat with a crew of 20-50 men. Later, the vessels became larger, and 200 tonnes deadweight ships were able to carry several hundred passengers and were quite commonly used (Manguin 1980: 266-276). Thus the cargo quickly diversified to include natural resources classified as "bulk goods". These items reflect the fact that both high value and low-value products were carried on the maritime routes (Heng 2009: 30).

Another trend was the increasing importance of maritime routes. Between the fourth and sixth centuries $\mathrm{AD}$, the overland caravan trading routes between China and the West were closed off by developments in central Asia, resulting in a shift to the oceanic connection. Despite the fall of the Han dynasty, trade between South China and India continued to flourish through a complex and increasingly integrated maritime 
trading system that linked the eastern Mediterranean, the Middle East, the East African coast, Persia, and India with China and Southeast Asia. Global trade reached its next apex during the Tang Dynasty (618-907) when trade flourished to unprecedented levels. This period also coincided with the Byzantine Empire, Persia and the Abbassid Empire which were all kept relatively stable.

The Mongol/Yuan Dynasty (1271-1368) introduced essential innovations in the overland routes: it eliminated a significant number of toll-gates and corruption on the Silk Road, making it cheaper for travellers. Trade routes became more convenient, easier to use and safer than ever before. The maritime routes also expanded, from private trade and shipping networks in the South China Sea under the Song Dynasty to a more aggressive foreign trade policy under the Yuan Dynasty that favoured a government maritime network.

The period between the thirteenth and mid-fifteenth centuries marked a distinct and vital phase in the development of global trade as a result of a massive increase in Chinese maritime networks to southern Asia. During this period, the Chinese built the world's largest merchant ships and a supporting navy that continued to expand commerce far and wide thereby enabling the Chinese traders to take control of the spice trade in Southeast Asia and ranging into the Indian Ocean (Sen 2006: 421).

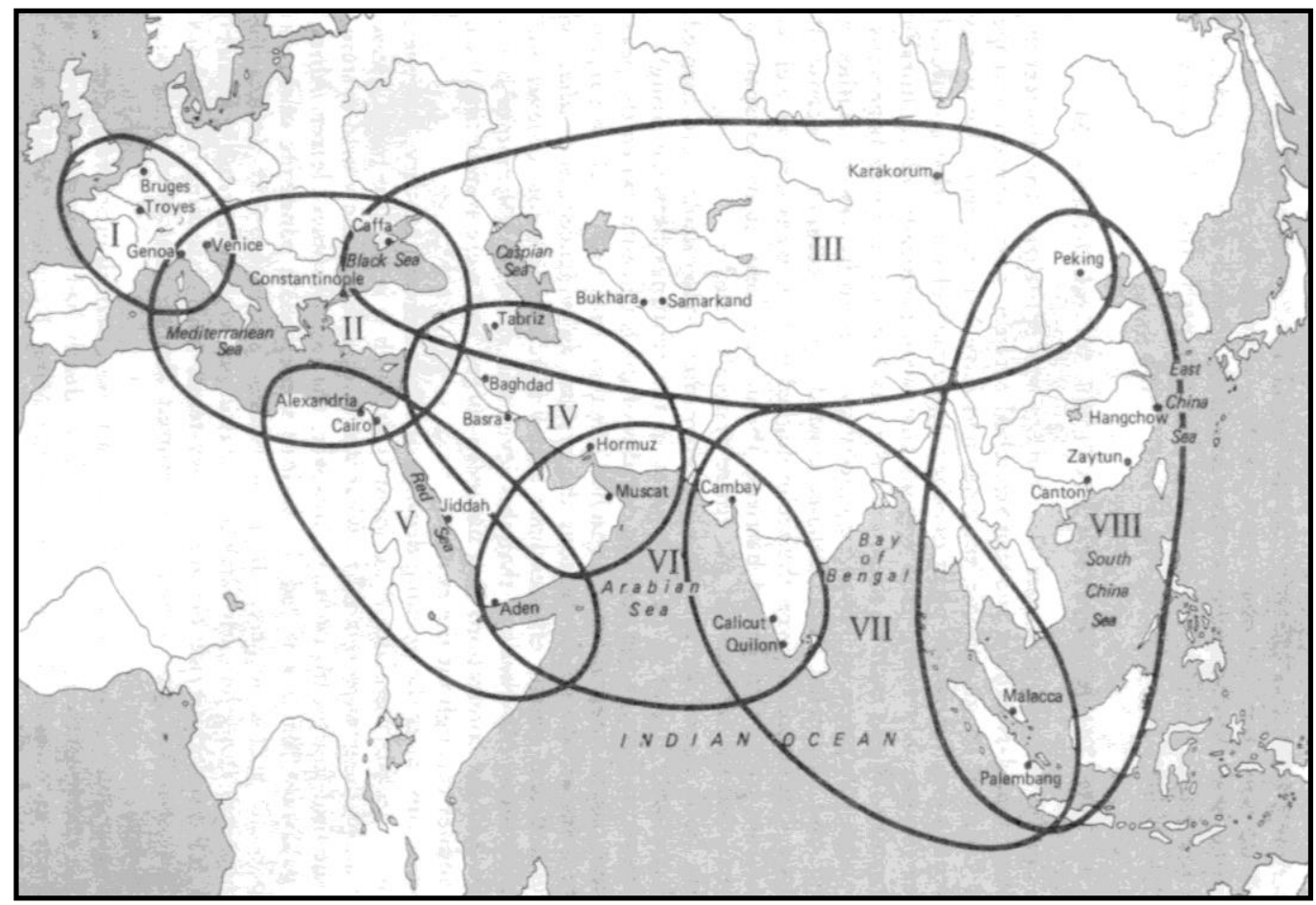

Figure 6: The Eight Circuits of the Thirteenth Century World System Source: Abu-Lughod, J.L, (1989: 34) 
In summary, by the fourteenth century AD, the Mongol Empire stretched from Mongolia and Siberia in the north to the South China Sea in the south, inextricably linking Europe and Asia ushering in an era of frequent and extended contacts between East and West. The Yuan Dynasty's aggressive trade policies crystallized the emergence of the medieval World System as postulated by Abu-Lughod. This medieval World System was not functionally integrated around a central core, but is segmentary, consisting of a series of regionally defined trading subsystems - each with its core and periphery - that interlocked to create a single world trading system extending from Europe to China. In this system, the Indian Ocean and its two vast gulfs, the Red Sea and the Persian, form the critical link, connecting the Mediterranean basin, West Asia and East Africa to the Indian subcontinent, itself the bridge between the Indian Ocean circuit and China via Southeast Asia (Figure 6).

The "geographical heartland" of the system was (I) Europe, (II) the Eastern Mediterranean, the land bridge which guarded three routes of access, namely (III) the northern route from Constantinople to Central Asia (and China), (IV) the central route from the Mediterranean to the Indian Ocean via Baghdad, Basra and the Persian Gulf. The third was the southern route that linked Alexandria, Cairo with (V) the Red Sea, (VI) the Indian Ocean, (VII) the Bay of Bengal and (VIII) the South China Sea (AbuLughod 1989: 139).

The southern route components (VI, VII and VIII) were not only geographical segments but cultural domains and no single power dominated this route. "Port emporia, the meeting place from the three cultural zones emerged as strategic beachheads. The Straits of Malacca became a cultural melting pot with numerous trading entrepots that dotted the coast with a diverse population of Malays, Sumatrans, Javans and long term foreign residents or trade diasporas" (Abu-Lughod 1989: 259).

\section{Trade Diasporas in Maritime Southeast Asia}

This concept was used by Curtin (1984) in his landmark effort, Cross-Cultural Trade in World History and employed in a recent Special Issue of the Journal of the Economic and Social History of the Orient. Hugh Clark's introduction on "Maritime Diasporas in Asia before Da Gama" supplies a definition, viz., "the trade diaspora was a community of merchants of common origin gathered in a foreign city or culture in order to conduct trade. Such diasporas coexisted with, intermingled with, and sometimes become one with their host society. In the process, they were media for cross-cultural exchange and ultimately for the dissemination of the cultural phenomena" (Clark 2006: 391).

There is strong evidence of trade diasporas in the coastal port polities in Southeast Asia from the early centuries of the first millennium. Various trade diasporas, mainly of Indian, Arab Moslem and Chinese origins emerged in the region to play an active role in the economic development of maritime Southeast Asia. By the fourteenth and fifteenth centuries, these trade diasporas had contributed to the development of trade in the Indian Ocean and the South China Sea just before the entry of the Europeans into the region in the post-1500 era.

By the late eighth-century Arab Muslim traders had settled in Canton (Guangzhou) and Zaytun (present-day Quanzhou) in large numbers, bypassing Southeast ports and going direct to these Chinese ports. In 878 A.D., a revolt against 
the Tang government sacked Canton and killed many of the foreign traders residing there (Curtin 1984: 108). This led to an exodus of Arab Moslem traders in Canton and Zaytun to seek refuge in Southeast Asian ports and to focus their trade with Southeast Asia rather than going directly to China. Thus, by the late ninth century, instead of bypassing Southeast Asian ports, traders preferred to sell their cargo in maritime Southeast Asia, thus generating Arab trade diasporas in the region. One such port town was Kalah Bar, (probably modern Kedah) on the west coast of the Malay Peninsula (Hourani 1963: 71). Kedah's location at the entrance of the Straits of Melaka made it a popular destination of Arab traders. Kedah soon became the terminus for Muslim ships from the Gulf coast where they would meet the ships coming from China. Trade was carried on this way until the beginning of the tenth century (Hirth and Rockhill 1966: 18).

From the eleventh to thirteenth centuries new trade diasporas expanded in maritime Southeast Asia. Merchants guilds from India competed with one another to control the trade of maritime Southeast Asia. This resulted in the establishment of Indian trade diasporas in harbours along the Straits of Melaka (Munoz 2006: 194).

As for Chinese trade diasporas in maritime Southeast Asia, Chang Pin-tsun points to sporadic Ming records which indicate that some sojourners lived in Southeast Asia in the fourteenth century suggesting the possibility of the existence of Chinese settlements in Southeast Asia although no records are available to indicate how widespread these settlements were to make up a significant Chinese diaspora. By the early decades of the fifteenth century, however, the profile of this diaspora and of a busy Chinese trade network had emerged more clearly based on Chang's analysis of available sources. Factors such as population pressure in China and economic opportunities overseas together with other causes such as developments in shipping technology, commercial entrepreneurship, tribute trade and maritime prohibition as well as political networking, such as Cheng Ho's voyages, each played a mutually reinforcing role in contributing to the rise of the Chinese trade diaspora in this region (Chang 1991: 14-15, 26).

By the fifteenth century, this diaspora had replaced Arab and Indian traders, who had been very active in this region in the previous centuries. Chinese traders dominated the maritime trade of the South China Sea after 1433 when Chinese junks seem to have rarely ventured beyond the Melaka Straits. Melaka and Aceh in northwest Sumatra became the terminal ports for Chinese seafarers; the world beyond the Straits was left to the West Asians (Chang 1991: 16). Melaka emerged as one of the first major emporiums where Chinese, West and Southeast Asians met, and it prospered throughout the fifteenth century forging links and significant regional trade networks (See Figure 7).

Besides Melaka, many other commercial centres appeared similarly, often mainly as the result of Chinese trading activities. This applies to Siam (Ayutthaya), Patani, Java (Sunda), Sumatra (Aceh), Palembang, Brunei, Sulu, Champa (Cha Ban) among others, all of which were recorded to have dynamic business activities in the fifteenth century. Some even enjoyed a sustained boom, lasting well into the sixteenth century, which continued until the end of the eighteenth century, despite European intrusion into this part of the world from the sixteenth century onward. "For a long time the presence of Europeans was helpful, rather than harmful, to the growth of this Chinese diaspora, and the consolidation of its power in the maritime economy" (Chang 1991: 13). 


\section{The Way Forward}

An interesting phenomenon which has emerged from the study of trade diasporas is what Curtin (1984) termed as "cultural blends" (p. 11). People of the trade diasporas are not only members of a society which comprises of communities of different cultures and backgrounds. All trade diasporas involve the inevitable interaction with their respective host societies and undergo a process of assimilation and eventually, cultural integration or acculturation in one form or another. Curtin brought out two possible extreme cases of a trade diaspora assimilation process; the first involving those communities which try to protect the integrity of their original culture by holding on to their religions, language, customs and traditions despite their role as cross-cultural brokers.

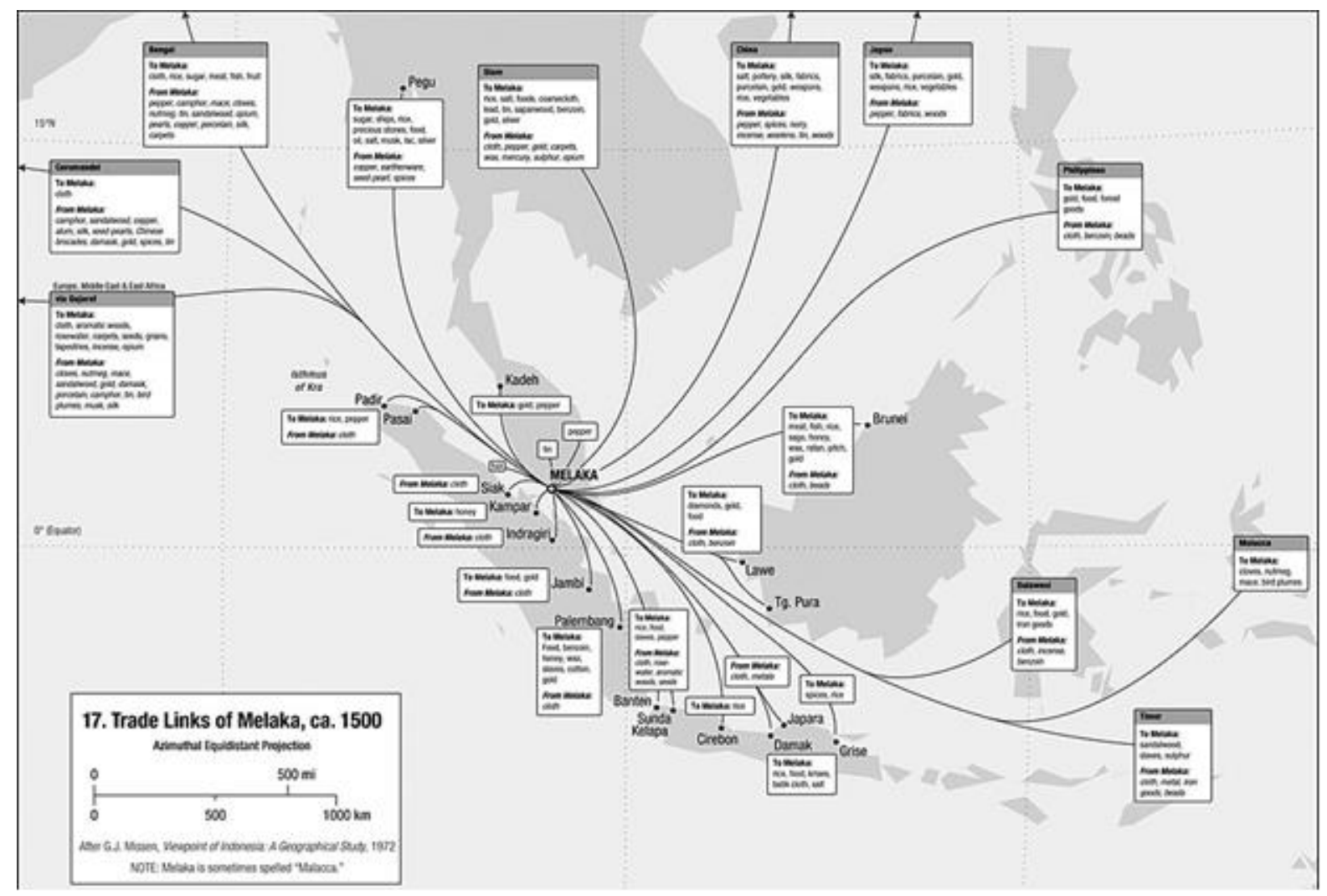

Figure 7: Trade Links of Malacca c. 1500

Source: Missen, J.G. (1972: 112)

At the other end of the spectrum, Curtin also brought out the case of sojourners and settlers who went abroad to trade without their women and ended up marrying or cohabitating with the local women. This led to the development of mixed communities, with several examples found in Southeast Asia. The Peranakans in Melaka is one of the many instances of communities which evolved as a result of the intermarriage of Chinese merchants (mainly from the Fujian province in south China) with local (mainly 
Javanese) women. Some of these mixed communities stabilized, even developing their patois and unique lifestyles. Under the Dutch colonial era in the seventeenth and eighteenth centuries, for example, Peranakan diasporas had their quarters in the towns where they thrived, enjoyed special status under colonialism and contributed to the development of trade and commerce in the region, lasting up to the second world war.

How hybrid trade diasporas such as the Chinese Peranakans, originated and evolved in maritime Southeast Asia forms a fascinating topic in the context of the impact of global trade on the rise and fall of trade diasporas. Some studies have been undertaken on the characteristics of Chinese Peranakan communities, most of which focused on their social identities, norms and practices. There is a case for more work to be undertaken comparing their development paths in the context of their host countries and also on their economic and social networks based on trade so as to add depth and dimension to the nature of cross-cultural exchanges in general, and the role of trade diasporas in the transformation of the socio-economic and cultural landscapes in selected regions, such as maritime Southeast Asia in particular. Such empirically-based studies can hopefully contribute more insights to the socio-economic impact of global trade on its participating communities. Indeed, Clark (2006) asserted that the current western scholarship on the Indian Ocean revealed that only recently has there been an acknowledgement of the importance of trade diasporas in early modern history, as well as for Europe - a recognition which has long been held in Southeast Asian studies.

\section{References}

Abu-Lughod, J. L. (1989). Before European Hegemony: The World System A.D. 12501350, New York: Oxford University Press.

Jamil, A., Darmawaty, Y., \& Wachyuni, S. (2004). Atlas Sejarah Indonesia dan Dunia (Indonesian and World Historical Atlas) Jakarta (accessed: http://ms.wikipedia.org/wiki/Fail:Southeast_Asia_trade_route_map_XIIcentury. jpg, 30/1/2012)

Beaujard, P. (2005). "The Indian Ocean in Eurasian and African World Systems Before the $16^{\text {th }}$ Century", Journal of World History, 16, 4: 411-466.

Beaujard, P. (2010). "From Three Possible Iron-Age World-Systems to a Single AfroEurasian World-System", Journal of World History, 21, 1: 1-43.

Bentley, J.H., \& Ziegler, H.F. (2005). Traditions and Encounters: A Global Perspective on the Past, New York: McGraw-Hill, $3^{\text {rd }}$ Edition.

Chaudhuri, K. N. (1985). Trade and Civilisation in the Indian Ocean: An Economic History from the Rise of Islam to 1750, Cambridge: Cambridge University Press.

Chang, P. (1991). "The First Chinese Diaspora in Southeast Asia in the Fifteenth Century". In Roderich Ptak and Rothermund Dietmar, (Eds.), Emporia, Commodities and Entrepreneurship in Asian Maritime Trade C. 1400-1750, Stuttgart: Steiner Verlag: 13-28. 
Clark, H. R. (2006). "Maritime Diasporas in Asia before Da Gama: An Introductory Commentary", Journal of the Economic and Social History of the Orient, 49, 4: 385-394.

Curtin, P. D. (1984) Cross Cultural Trade in World History, Cambridge: Cambridge University Press.

Frank, A.G. (1992), "The Centrality of Central Asia", Bulletin of Concerned Asian Scholars, 24, 2: 50-74.

Frank, A.G. (1999). Reorient: Global Economy in the Asian Age, Berkeley: University of California Press.

Frank A.G. \& Gills, B.K., eds. (1994). The World System: Five Hundred Years or Five Thousand? London: Routledge.

Heng, D. (2009). Sino-Malay Trade and Diplomacy from the Tenth through the Fourteenth Century, Athens: Ohio University Press.

Hill, J.E. (2009). Through the Jade Gate to Rome: A Study of Silk Routes During the Later Han Dynasty First and Second Centuries AD; An Annotated Translation of the Chronicles of the Western Regions from the Hou Hanshu, Appendix B: The Story of Sea Silk, 468-476, Book Surge.

Hourani, G. F. ( 1963). Arab Seafaring in the Indian Ocean in Ancient and Early Medieval Times, Beirut: Khayats Oriental Reprints No. 3.

Hirth, F., \& Rockhill, W.W. (translators) (1966). Chau Ju-Kua: His work on the Chinese and Arab Trade in the Twelfth and Thirteenth Centuries, entitled Chufan-chi, New York: Paragon Book Reprint Corp.

Lawton, J. (2004). Silk, Scents and Spices, Tracing the World's Great Trade Routes: The Silk Road, the Spice Route, the Incense Trail, Paris: UNESCO and Belitha Press.

Legge, J. (translator) (1886). A Record of Buddhistic Kingdoms: Being An Account of the Chinese Monk Fa-hsien of His Travels, University of Adelaide Library, ebooks@Adelaide (Accessed 1/8/2010).

Lockhard., C. (2010). "The Sea Common to All: Maritime Frontiers, Port Cities, and Chinese Traders in the Southeast Asian Age of Commerce ca. 1400-1750", Journal of World History, 21, 2: 219-247.

Manguin, P. (1980). "The Southeast Asian Ship", Journal of Southeast Asian Studies, 11, 2: 266-276.

Miller, J. I. (1969). The spice trade of the Roman Empire 29 B.C. to A.D. 641. Oxford: Clarendon Press.

Missen, J.G. (1972). Viewpoint of Indonesia, A Geographical Study (Asia Society Education, @sites.asiasociety.org/education/islam_in.../17MalaccaTrade.pdf, accessed, 1/12/2012)

Munoz, P.M. (2006). Early Kingdoms of the Indonesian Archipelago and the Malay Peninsula, Singapore: Editions Didier Millet.

Reid, A. (2000). Charting the Shape of Early Modern Southeast Asia, Chiang Mai: Silkworm Books.

Sen, T. (2006). "The Formation of Chinese Maritime Networks to Southern Asia, 12001450", Journal of the Economic and Social History of the Orient, 49, 4: 421453. 
Shen, F. W. (1996). Cultural Flow Between China and the Outside World, Beijing: Foreign Language Press.

Wallerstein, I. (1974). The Modern World-System: Capitalist Agriculture and the Origins of the European World-Economy in the Sixteenth Century, New York: Academic Press.

Date Received: 15 September 2018 Date of Acceptance: 15 June 2019 